\title{
The first records of Aegopinella ressmanni (Westerlund, 1883) in the Czech Republic extends its distribution range northwards
}

\author{
Michal HoRsÁK ${ }^{1} \&$ JAN MYŠÁK ${ }^{2}$ \\ ${ }^{I}$ Department of Botany and Zoology, Masaryk University, Kotlářská 2, Brno, CZ-61137, Czech Republic, e-mail: horsak@sci.muni.cz \\ ${ }^{2}$ Rösslerova 1414, Česká Třebová, CZ-56002, Czech Republic, e-mail: anczoviczka@seznam.cz
}

\begin{abstract}
Horsák M. \& MYšÁ́ J., 2008: The first records of Aegopinella ressmanni (Westerlund, 1883) in the Czech Republic extends its distribution range northwards. - Malacologica Bohemoslovaca, 7: 47-50. Online serial at $<$ http://mollusca.sav.sk> 4-Jun-2008.
\end{abstract}

\begin{abstract}
A topsoil-dwelling Eastern Alpine terrestrial snail Aegopinella ressmanni (Westerlund, 1883) was found for the first time in the Czech Republic at nine sites in E Bohemia. Abundant populations of the species occurred in wet habitats of the Tichá Orlice River valley between the village of Hnátnice and the town of Brandýs nad Orlicí. These Czech populations were found $250 \mathrm{~km}$ far from the known northernmost sites in Germany and Austria.
\end{abstract}

Key words: Aegopinella ressmanni, Czech Republic, first record, northernmost occurrence

\section{Introduction}

Aegopinella ressmanni is an Eastern Alpine terrestrial snail with the known distribution in Slovenia, Croatia, SW Hungary, and SE Austria from which it extends to NE Italy and SE Germany (SEIDl 1978, KLemm 1974, KerNeY et al. 1983, Cossignani \& Cossignani 1995). It is a typical topsoil-dwelling species inhabiting different types of wet forest habitats in a rather broad altitudinal range (in Austria from 250 to $1700 \mathrm{~m}$ a.s.1., KLEMM 1974). Having the shell width up to $15 \mathrm{~mm}$ it belongs to the largest species of the genus with and it is the largest European Aegopinella species (Kerney et al. 1983). During the research of land snails in the Tichá Orlice River Valley A. ressmanni was found for the first time in the Czech Republic.

\section{Material and methods}

The study area stretches between the Letohrad and Choceň Towns in NE Bohemia (Czech Republic); along the Tichá Orlice River line between coordinates $50^{\circ} 02^{\prime} 07^{\prime \prime} \mathrm{N}$, $16^{\circ} 29^{\prime} 56^{\prime \prime} \mathrm{E}$ and $50^{\circ} 00^{\prime} 08^{\prime \prime} \mathrm{N}, 16^{\circ} 13^{\prime} 44^{\prime \prime}$ E. Molluscs assemblage were sampled in Autumn 2007 using a standard sampling procedure (CAMERon \& Pokryszko 2005), i.e. one person searched by eye in all appropriate microhabitats for 1 hour and litter samples were taken from four quadrats (each measuring $25 \times 25 \mathrm{~cm}^{2}$ ) at each site (i.e. a plot of $100 \mathrm{~m}^{2}$ ). Snail assemblages were collected at 33 sampling sites situated on both river banks and regularly distributed along the studied river stretch; 11 sites in the river alluvium and 22 sites in slopes of the valley. In February 2008 additional collecting (just eye search) was done in order to (1) obtain live specimens for anatomical studies and (2) find out whether the species occurs in the river stretches below and above the stretch where it was already found. Thus, the whole investigated river stretch extends between the Verměrovice Village and the Boro- hrádek Town $\left(50^{\circ} 00^{\prime} 02^{\prime \prime} \mathrm{N}, 16^{\circ} 32^{\prime} 09^{\prime \prime} \mathrm{E}\right.$ and 5005'52" N, $\left.16^{\circ} 05^{\prime} 49^{\prime \prime} \mathrm{E}\right)$. Nomenclature is according to JUŘIČKOVÁ et al. (2007) with several up-to-date changes.

\section{Results and discussion}

Aegopinella ressmanni was found at nine sites in the valley of the Tichá Orlice River (NE Bohemia) between the Hnátnice Village and the Brandýs nad Orlicí Town (Appendix 1, Fig. 1). The species was found in abundant populations and it mostly belonged to the dominant species of the assemblages (Tab. 1). The majority of populations occurred in the alluvium ( 7 sites) and only another two (out of 22 sites) were found on the valley slopes. The habitats were wet, covered mostly by sparse alder, ash and willow growths. The river alluvium sites were productive and nutrient-rich with a rich herb layer dominated by Urtica dioica, Aegopodium podagraria, Galium aparine, Cirsium oleraceum and including some common invasive species Impatiens spp. and Reynoutria spp. Those two slope sites were rock screes, also relatively wet.

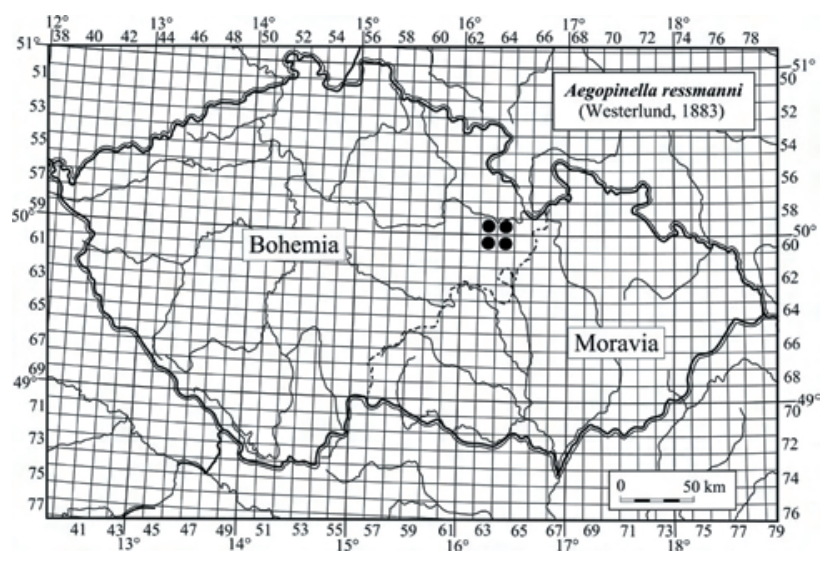

Fig. 1. Known distribution of Aegopinella ressmanni in the Czech Republic. 
The presented findings significantly extend the known recent distribution of the species; the sites are situated 250 $\mathrm{km}$ far from the nearest known northernmost occurrences in Upper Bavaria and Upper Austria (KLemm 1974, SeIDL 1978). Since they are largely isolated the origin of these E-Bohemian populations is unknown. The main problem is that the malacological survey of the area has never included the river valley; only the slopes on calcium-rich sandstone bedrock were investigated (see JUŘIČKOVÁ et al. 2006) and thus there are no data elucidating a question of the population origin. However, the fact that the species was found mostly at semi-natural sites with invasive vegetation indicates a recent spreading connected with human activities. On the other hand, its autochthonous occurrence
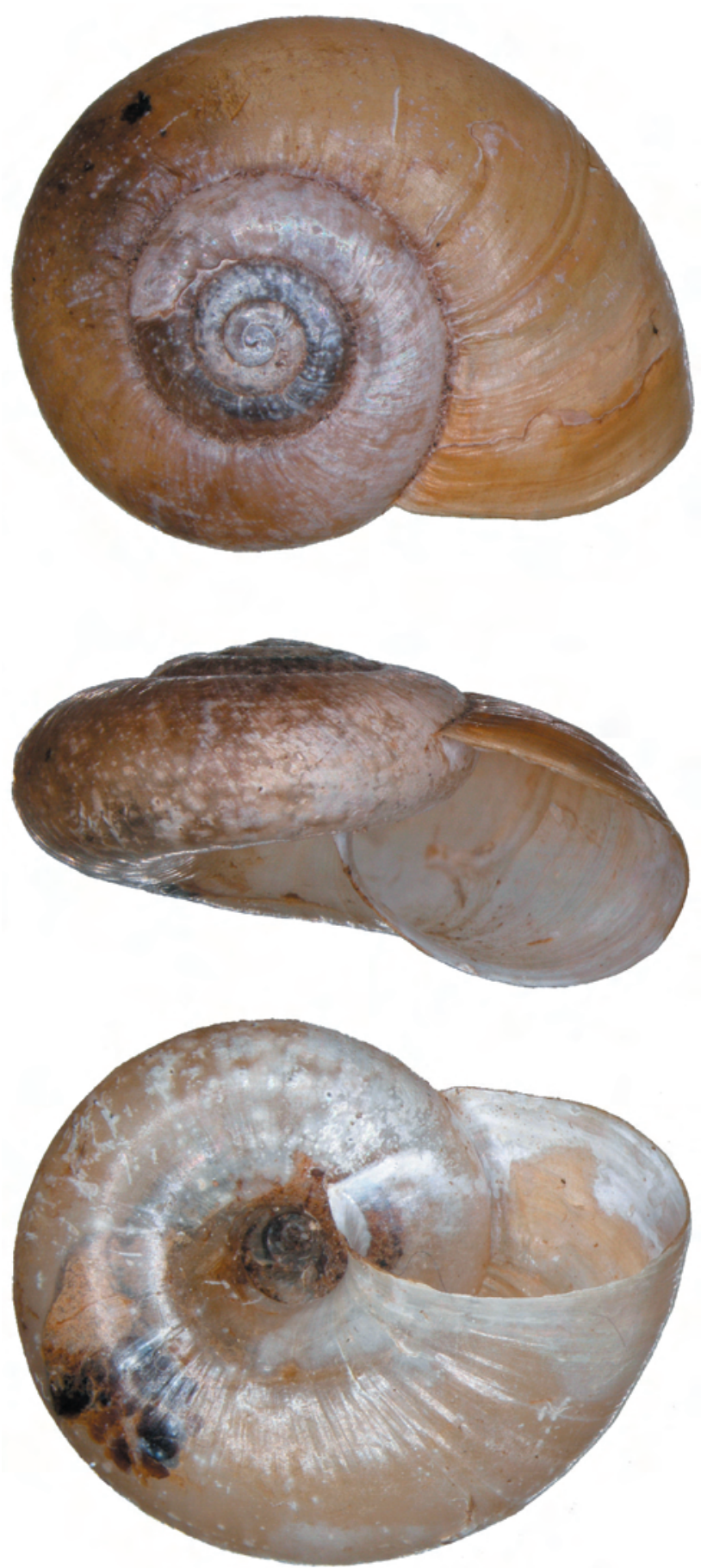

Fig. 2. Adult shell of Aegopinella ressmanni from site No. 5; height $=12.6 \mathrm{~mm}$, width $=6.1 \mathrm{~mm}$. in this area cannot be ruled out since several other Alpine snails - Itala ornata, Cochlodina costata commutata, Aegopis verticillus (LožEK 1956, KERNEY et al. 1983) - have their isolated distributions here. Moreover, from fossil data we know that $A$. ressmanni was a member of our fauna during warm Pleistocene periods; it is considered as an index species of the last Interglacial (LožEK 1955, 1964, HORÁČEK \& LOŽEK 1988). From Early Pleistocene it was documented even from south Poland near to the Krakow Town (STwORZEwicz 1975). Unfortunately, it is practically impossible to make a reliable conclusion about the origin of Bohemian populations without having exact fossil evidence.

\section{Identification notes}

It might be difficult or even impossible to correctly identify "large" species of the genus Aegopinella without using anatomical characters of their genitalia (HudEC 1964, KERNEY et al. 1983). Luckily it is not the case of $A$. ressmanni, which possesses several reliable identification characters

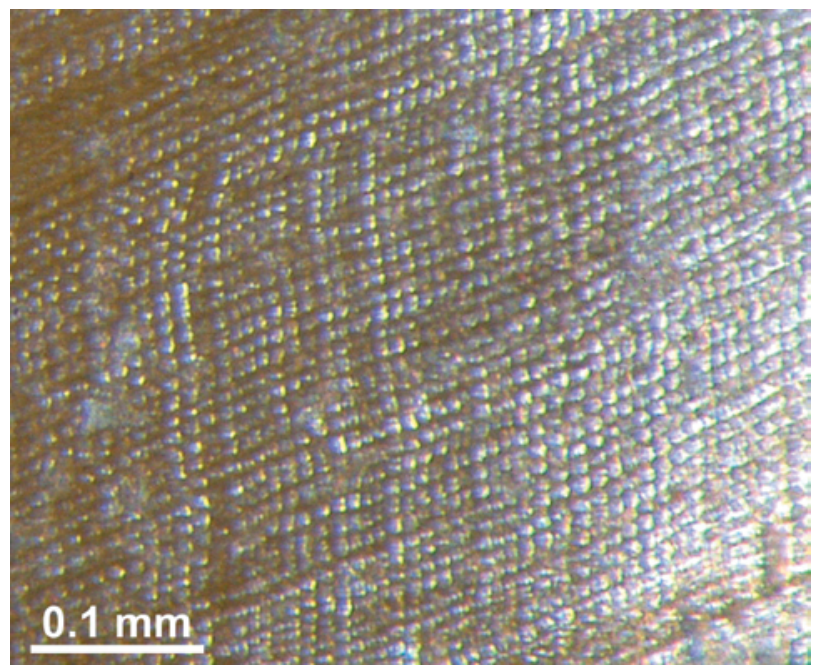

Fig. 3. Microstructure of shell of Aegopinella ressmanni from site No. 5.

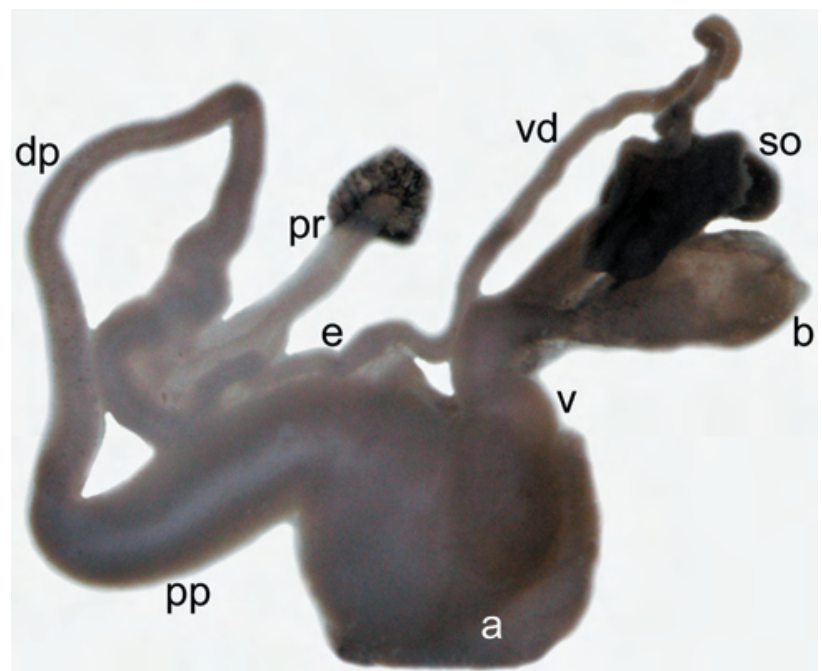

Fig. 4. Reproductive organs of Aegopinella ressmanni from site No. 5.; only the part with diagnostic characters is shown: a - atrium, b - bursa, dp - distal part of penis, e - epiphallus, pp - proximal part of penis, $\mathrm{pr}$ - penial retractor muscles, so - spermoviductus, vd - vas deferens, $\mathrm{v}-$ vagina. 
on its shell. At the first look the shell of an adult is obviously larger than those of other Aegopinella species (collected specimens had shells up to $14 \mathrm{~mm}$ wide). The impression of a large shell is further reinforced by a broadly opened mouth (Fig. 2). However, a fully reliable character is on the shell surface, which has a fine but noticeable "squared" microstructure that consists of irregular radial growth lines crossed by spiral striae (Fig. 3). The similar structure has only Aegopinella pura; the other species have only very fine striae. Fortunately, there is no risk of misidentification of these two species due to absolutely distinct dimensions of their shells (A. pura growths up to $4.5 \mathrm{~mm}$ and thus it has also baby whorls significantly smaller). We have also checked our identification using the anatomical characters of the species' reproductive organs, which were published by SEIDL (1978) and we found a perfect accordance with our material (Fig. 4).

\section{Acknowledgements}

The manuscript preparation was supported by the long-term research plans of Masaryk University (Czech Ministry of Education, MSM 0021622416).

\section{References}

Cameron R.A.D. \& Pokryszko B.M., 2005: Estimating the species richness and composition of land mollusc communities: problems, consequences and practical advice. - Journal of Conchology, 38: 529-548.

Cossignani T. \& Cossignani V., 1995: Atlante delle conchiglie terretri e dulciacquicole italiane. - L'Informatore Piceno, Ancona, $208 \mathrm{pp}$.

Hudec V., 1964: Zum Vorkommen der Schnecke Aegopinella epipedostoma (Fag.) und der anderen Arten der Gattung Aegopinella Lindh. in der Tschechoslowakei. - Acta Mus. Nat. Pragae, B 20: 119-132.

JuŘičKová L., Horsák M. \& Hrabáková M., 2006: Molluscs of the Peliny Natural Reserve near Choceň (East Bohemia, Czech Republic). - Malacologica Bohemoslovaca, 5: 10-13.

JuŘičKová L., Horsák M., Beran L. \& Dvořák L., 2007: Check-list of the molluscs (Mollusca) of the Czech Republic. - http:// mollusca.sav.sk/malacology/checklist.htm (last update: 18. 6 . 2007).

Kerney M.P., Cameron R.A.D. \& Jungbluth J.H., 1983: Die Landschnecken Nord- und Mitteleuropas. - Verlag Paul Parey, Hamburg und Berlin, 384 pp.

KLEMM W., 1974: Die Verbreitung der rezenten Land-Gehäuse-Schnecken in Österreich. - Denkschriften der Österreichischen Akademie der Wissenschaften, 117: 1-503.

LožEK V., 1955: Měkkýši československého kvartéru [Mollusken des Tschechoslovakischen Quartärs]. - Rozpravy Ústředního ústavu geologického, Vol. 31, ČSAV, Praha, 510 pp. (In Czech)
LožEK V., 1956: Klíč československých měkkýšů [Key of Czechoslovak Molluscs]. - Vydavatelstvo SAV, Bratislava, 437 pp. (In Czech)

LOžEK V., 1964: Quartärmollusken der Tschechoslowakei. - Rozpravy Ústředního ústavu geologického, Vol. 31, ČSAV, Praha, $374 \mathrm{pp}$.

HorÁČEK I. \& LožEK V., 1988: Palaeozoology and the Mid-European Quaternary past: scope of the approach and selected results. - Rozpravy Československé akademie věd, Řada matematických a prírodních věd, 98(4): 1-102.

Pruner L. \& Míka P., 1996: Seznam obcí a jejich částí v České republice s čísly mapových polí pro sít’ové mapování fauny [List of settlements in the Czech Republic with associated map field codes for faunistic grid mapping system]. - Klapalekiana, 32 (Suppl.): 1-175.

SeIDL F., 1978: Aegopinella ressmanni (Westerlund) in ihrem nördlichsten Verbreitungsgebiet (Vorkommen, Begleitfauna, Biologie). - Mitteilungen der Zoologischen Gesellschaft Braunau, 3(5/7): 111-124.

Stworzewicz E., 1975: Aegopinella lozeki n.sp. and Aegopinella ressmanni (West.) (Gastropoda, Zonitidae) from the Early Pleistocene of Poland. - Acta zool. cracov., Kraków, 20(12): 481-487.

Appendix 1. List of known sites of Aegopinella ressmanni in the Czech Republic. Data in the list are as follows: number of the site, geographical co-ordinates (N, E) (Geobáze digital map of the Czech Republic 1: 100 000), code of the mapping grid for faunistic mapping according to PRUNER \& Míka (1996), name of the nearest settlement, elevation (m a.s.l., approximately), description of the site, number of alive individuals/empty shells (ex.), date of investigation. All the sites were investigated by Jan Myš́k.

$1-50^{\circ} 00^{\prime} 23.2^{\prime \prime}, 16^{\circ} 27^{\prime} 46.2^{\prime \prime}, 5964$, Hnátnice, an willow growth in the confluence of the Potočnice brook and the Tichá Orlice River, 357 m, 16 Oct 2007, 164/122 ex.; 2 - 4959'05.9", $16^{\circ} 26^{\prime} 07.8^{\prime \prime}, 6064$, Černovír, a woody slope on the left bank of the Tichá Orlice River northwards the village, $346 \mathrm{~m}, 6$ Oct 2007, 24/2 ex.; 3 - 4959'10.6", 16²6'06.7", 6064, Václavov, an alder growth on the right bank of the Tichá Orlice River northwards the Černovír Village, 324 m, 7 Oct 2007, 59/11 ex.; 4 - 49 $59^{\prime} 01.6^{\prime \prime}, 16^{\circ} 24 ' 47.5^{\prime \prime}, 6064$, Oldřichovice, wet woody rock slopes under the road no. 360, 322 m, 19 Sep 2007, 20/18 ex.; 5 $-49^{\circ} 59^{\prime} 02.0^{\prime \prime}, 16^{\circ} 24^{\prime} 51.3^{\prime \prime}, 6064$, Oldřichovice, an willow growth on the left bank of the Tichá Orlice River under the village, 315 m, 24 Sep 2007, 49/12 ex.; 6 - 4958'07.6", 16²2'44.9", 6064 , Kerhartice, an alder and willow growth on the left bank of the Tichá Orlice River E of the village, 335 m, 18 Sep 2007, 57/ 18 ex.; 7 - 4958'55.5", 16²0'08.0", 6064, Sudislav nad Orlicí, an alder growth on the left bank of the Tichá Orlice River $1.5 \mathrm{~km}$ SE of the village, 331 m, 22 Aug 2007, 43/9 ex.; 8 - 49 59'48.7", $16^{\circ} 19^{\prime} 35.0^{\prime \prime}, 6063$, Bezpráví, an ash growth on the right bank of the Tichá Orlice River SW of the village, 325 m, 25 Jul 2007, 45/5 ex.; 9 - 5000'01.8", 16¹8'09.2", 5963, Brandýs nad Orlicí, a shrubby former pasture on the left bank of the Tichá Orlice River $1 \mathrm{~km}$ E of the town, $276 \mathrm{~m}, 23 \mathrm{Jul} 2007,14 / 0$ ex. 
Table 1. Land snail species co-occurred with Aegopinella ressmanni; numbers of recorded specimens (both alive and empty shells) are given. The site numbers as in the Appendix.

\begin{tabular}{|c|c|c|c|c|c|c|c|c|c|}
\hline Species / Site & 1 & 2 & 3 & 4 & 5 & 6 & 7 & 8 & 9 \\
\hline Aegopinella minor (Stabile, 1864) & & & & & & & & 1 & 1 \\
\hline Aegopinella pura (Alder, 1830) & & & & 2 & & 5 & & 1 & 1 \\
\hline Aegopinella ressmanni (Westerlund, 1883) & 286 & 26 & 70 & 38 & 59 & 75 & 52 & 50 & 14 \\
\hline Aegopis verticillus (Lamarck, 1822) & & 1 & 1 & & & & 1 & & 1 \\
\hline Alinda biplicata (Montagu, 1803) & 8 & 11 & 3 & 182 & 1 & 95 & 13 & 17 & 7 \\
\hline Arianta arbustorum (Linnaeus, 1758) & 4 & 2 & 4 & 16 & 6 & 28 & 4 & 5 & 6 \\
\hline Arion silvaticus (Lohmander, 1937) & & 1 & & & & & & & \\
\hline Arion distinctus Mabille, 1868 & & 3 & 12 & 3 & & & & & \\
\hline Arion lusitanicus Mabille, 1868 & & & 6 & & 1 & 7 & & 13 & 56 \\
\hline Arion fuscus (O.F. Müller, 1774) & 1 & 1 & 3 & & & & 1 & & \\
\hline Boettgerilla pallens Simroth, 1912 & 4 & 3 & 2 & 6 & 2 & 3 & & & \\
\hline Carychium minimum O.F. Müller, 1774 & & 22 & 6 & & 92 & & 3 & & 2 \\
\hline Carychium tridentatum (Risso, 1826) & & 34 & & & 26 & 2 & 10 & & 1 \\
\hline Cepaea hortensis (O.F. Müller, 1774) & 7 & & 2 & 7 & 2 & 2 & 2 & & 3 \\
\hline Clausilia parvula Férussac, 1807 & & & & 75 & & & & & \\
\hline Cochlicopa lubrica (O.F. Müller, 1774) & 1 & & 3 & & 29 & 17 & 10 & 6 & 6 \\
\hline Cochlodina costata commutata (Rossmässler, 1836) & & & & 94 & & & 2 & & \\
\hline Cochlodina laminata (Montagu, 1803) & & 60 & & & & & 3 & 7 & 5 \\
\hline Daudebardia rufa (Draparnaud, 1805) & & 23 & & 8 & 2 & & 2 & 2 & 2 \\
\hline Discus perspectivus (Megerle von Mühlfeld, 1816) & & & & & & & 12 & & \\
\hline Discus rotundatus (O.F. Müller, 1774) & & 14 & & 44 & & 9 & 8 & 4 & 3 \\
\hline Ena montana (Draparnaud, 1801) & 2 & 12 & 3 & 12 & & 2 & 1 & & \\
\hline Eucobresia diaphana (Draparnaud, 1805) & 5 & & 24 & & 5 & 8 & 3 & & \\
\hline Euconulus fulvus (O.F. Müller, 1774) & & & & & & & 1 & & \\
\hline Faustina faustina (Rossmässler, 1835) & & & & 27 & & & & & \\
\hline Fruticicola fruticum (O.F. Müller, 1774) & 14 & & 7 & & 15 & 80 & 52 & 27 & 8 \\
\hline Helicigona lapicida (Linnaeus, 1758) & & 4 & & 8 & & & & & \\
\hline Helix pomatia Linnaeus, 1758 & 1 & 1 & & & & 6 & 10 & 2 & 5 \\
\hline Isognomostoma isognomostomos (Schröter, 1784) & & 9 & & 7 & & 1 & 3 & & \\
\hline Laciniaria plicata (Draparnaud, 1801) & & 27 & & 151 & & & & & \\
\hline Lehmannia marginata (O.F. Müller, 1774) & & 4 & & 2 & & & & & \\
\hline Limax cinereoniger Wolf, 1803 & & 1 & & 4 & 2 & & & & \\
\hline Macrogastra ventricosa (Draparnaud, 1801) & & 3 & & 18 & & & 2 & 1 & \\
\hline Monachoides incarnatus (O.F. Müller, 1774) & 11 & 15 & 9 & 24 & 15 & 68 & 23 & 13 & 14 \\
\hline Monachoides vicinus (Rossmässler, 1842) & & 8 & & & & & 7 & 1 & \\
\hline Oxychilus cellarius (O.F. Müller, 1774) & & 2 & 1 & 5 & & 2 & & & \\
\hline Oxychilus depressus (Sterki, 1880) & & & & 4 & & & & & \\
\hline Perpolita hammonis (Ström, 1765) & 4 & & 3 & & 3 & 15 & 19 & 2 & 1 \\
\hline Petasina unidentata (Draparnaud, 1805) & & 11 & & 6 & & & & & \\
\hline Punctum pygmaeum (Draparnaud, 1801) & & 6 & & 9 & 4 & & 2 & & \\
\hline Semilimax semilimax (J. Férussac, 1802) & 53 & 3 & 50 & 3 & 18 & 47 & 3 & 17 & 1 \\
\hline Succinea putris (Linnaeus, 1758) & 2 & & 5 & & 6 & 9 & 1 & 18 & 24 \\
\hline Succinella oblonga (Draparnaud, 1801) & & & & & & 2 & & & \\
\hline Tandonia rustica (Millet, 1843) & & 6 & & 3 & & & & & \\
\hline Trochulus sericeus (Draparnaud, 1801) & 2 & & & 1 & 5 & 35 & & 6 & 3 \\
\hline Urticicola umbrosus (C. Pfeiffer, 1828) & & & & & 1 & & & & \\
\hline Vallonia costata (O.F. Müller, 1774) & & & & & & & & 1 & \\
\hline Vertigo alpestris Alder, 1838 & & & & 3 & & & & & \\
\hline Vertigo pygmaea (Draparnaud, 1801) & & & & & & 1 & & & \\
\hline Vertigo substriata (Jeffreys, 1833) & & & & & & 4 & & & \\
\hline Vitrea contracta (Westerlund, 1871) & & & & & 1 & & & & \\
\hline Vitrea crystallina (O.F. Müller, 1774) & 3 & 2 & & & 9 & 5 & & & 3 \\
\hline Vitrea diaphana (Studer, 1820) & & 3 & & 4 & & & 7 & 1 & \\
\hline Vitrina pellucida (O.F. Müller, 1774) & 1 & & 8 & & & & 74 & 23 & 20 \\
\hline Zonitoides nitidus (O.F. Müller, 1774) & & & & & & 2 & & 1 & 26 \\
\hline
\end{tabular}

